Background: Palliative care is the active comprehensive care of a terminally ill patient and his family. The quality of life of palliative patients is used to measure the effectiveness of treatment, as well as to show the most important aims in the patient's care. The objective of the present study was to assess the change of quality of life of hospitalized terminally ill palliative oncological patients, using the newly developed EORTC Core Quality of Life Questionnaire (QLQ-C15-PAL).

Material and methods: The study was performed in the Palliative Care Unit in the Hospital of Bonifratres Convent in Łódź. A group of hospitalized terminally ill palliative patients with lung, breast, colon or prostate cancer was analysed. Multi-item scales assessing physical and emotional functioning, single items of somatic symptoms and global quality of life estimated subjectively by patient were used. The trial was prospective and 121 questionnaires were finally included in the analysis.

Results and conclusions: The overall quality of life was in correlation with the type of diagnosed carcinoma, giving the best scores in prostate cancer and the poorest ones in lung carcinoma. During the end of life care performed in the Palliative Care Unit the subjective quality of life (QOL) and emotional functioning of patients did not worsen, and in some patients the above parameters improved. Some reduction of numerous somatic symptoms was observed. The different activities contributing to palliative care resulted in some reduction of several somatic symptoms (e.g. constipation, insomnia) determining the discomfort severity. The important factors negatively determining the overall QOL were fatigue and pain, eliminated partially only in some patients. The effectiveness of palliative care relating to overall QOL or improvement of several symptoms did not differ significantly among patients with various types of tumour.

Key words: quality of life, cancer, palliative care, end of life care.

\section{Assessment of change of quality of life in hospitalized terminally ill cancer patients}

\author{
Ocena zmian jakości życia pacjentów w terminalnej fazie choroby \\ nowotworowej
}

\section{Magdalena Jasińska', Michał Tracz ${ }^{2}$, Urszula Kurczewska, Daria Orszulak-Michalak ${ }^{1}$}

1Department of Biopharmacy, Medical University of Łódź, Poland

2Hospital of Bonifratres Convent in Łódź, Poland

\section{Introduction}

Cancer among infectious and cardiovascular diseases is the most common cause of death in the world. Nowadays, malignant carcinoma is diagnosed in 11 million patients per year and it accounts for around 7 million deaths due to cancer. In Poland, cancer is the recognized cause of $20 \%$ of deaths, and the most common ones include lung, colon, breast and prostate cancer $[1,2]$.

According to the World Health Organization (WHO), palliative care is the interdisciplinary specialty that aims to relieve suffering and improve the quality of care for patients with serious illness and their families. It is defined as active, total care integrating symptom and pain control with spiritual, psychological, social and financial factors and it is best practised as an interdisciplinary team model.

Quality of life (QOL) is a multidimensional concept that focuses on how disease and its treatment affects the individual. It is a multidisciplinary structure comprising a number of factors including physical ones (e.g. induced by the illness and its treatment), psychological and emotional factors relating to, among others, states of anxiety and depression, and finally social factors.

The above studies might be performed using several methods involving universal questionnaires (e.g. SF-36, EuroQol-5D) or specific ones considering typical conditions and factors determining particular diseases giving the possibility of comparative studies [3].

The quality of life of palliative patients is used to measure the effectiveness of treatment, as well as to show the most important aims in the patient's care. In modern oncology QOL has become a parameter of equal importance to other ones characterizing the effectiveness of treatment, e.g. 5-year survival rate, disease-free survival or neoplasm-controlled survival. Different scales for measuring QOL have been used including: specific global cancer indexes, Karnofsky index, Eastern Cooperative Oncology Group Performance Status, Specific Individual Cancer Indexes, and the Rotterdam Symptom Check List [4]. In our study the quality of life was assessed using the newly developed QLQ-C15-PAL questionnaire (Polish version) for terminally ill, palliative patients $[5,6]$. The QLQ-C15-PAL is recommended for use in patients with advanced, incurable, and symptomatic cancer with a median life expectancy of a few months.

In contrast to the numerous QOL studies using QLQ-C30, the assessment of QOL using QLQ-C15-PAL is relatively rare.

The objective of the present study was to assess the effectiveness of palliative care during the hospitalization period in palliative oncological, end-of- 
Wstęp: Opieka paliatywna stanowi aktywną, całościową opiekę nad nieuleczalnie chorym pacjentem i jego rodziną. Ocena jakości życia chorych umożliwia ocenę skuteczności prowadzonego leczenia, wskazując najważniejsze kierunki działań personelu medycznego. Celem pracy była ocena jakości życia hospitalizowanych pacjentów w terminalnej fazie choroby, objętych opieką paliatywną.

Materiat i metody: Badanie przeprowadzono w Szpitalu Zakonu Bonifratrów św. Jana Bożego w Łodzi na Oddziale Medycyny Paliatywnej, przy udziale pacjentów zakwalifikowanych do czterech grup: niedrobnokomórkowy rak płuca, rak piersi, rak prostaty, rak jelita grubego. Do oceny jakości życia wykorzystano formularz QLQ-C15-PAL, opracowany przez Europejską Organizację do Badania i Leczenia Nowotworów (EORTC). Badanie obejmowało analizę porównawczą jakości życia pacjentów chorych na ww. typy nowotworów oraz ocenę wpływu prowadzonych działań w zakresie opieki paliatywnej na redukcję poszczególnych objawów somatycznych, sprawność fizyczną, stan emocjonalny pacjentów oraz jakość życia w ich subiektywnej ocenie. Badanie miało charakter prospektywny. Badanie jakości życia odbywało się w cyklach tygodniowych; w czasie jego trwania zebrano 121 wypełnionych formularzy.

Wyniki i wnioski: Ogólna jakość życia pacjentów pozostawała w związku z rodzajem nowotworu pierwotnego. Najlepiej ocenili ją pacjenci z rakiem prostaty, najgorzej - pacjenci z rakiem płuca. Podczas pobytu chorych na Oddziale Medycyny Paliatywnej jakość życia w ich subiektywnej ocenie i stan emocjonalny nie uległy pogorszeniu, a u części badanych odnotowano pewną poprawę ww. parametrów. Działania prowadzone w ramach opieki u schyłku życia pozwolity na pewne osłabienie wpływu poszczególnych objawów somatycznych (np. zaparcia, bezsenność) na odczuwany stan upośledzenia i dyskomfortu. Istotnym czynnikiem negatywnie wpływającym na jakość życia pacjentów były dolegliwości bólowe, które zredukowano tylko u części pacjentów. Nie odnotowano zależności między efektywnością działań podejmowanych $w$ ramach prowadzonej opieki paliatywnej w odniesieniu do poprawy całkowitej jakości życia a rodzajem choroby nowotworowej.

Słowa kluczowe: jakość życia, choroba nowotworowa, opieka paliatywna, opieka u schyłku życia. life patients with the most common cancers (lung, breast, colon or prostate), considering the linkage between the outcomes and type of tumour.

\section{Material and methods}

The study was performed following the protocol approved by the Bioethics Committee (40/2007 from 11.09.2007). The trial lasted from February 2007 to April 2009. A group of hospitalized, palliative, end-of-life patients was recruited for the study according to the primary site of carcinoma: non-small lung cancer $(n=14)$, breast cancer $(n=7)$, colon cancer $(n=16)$ or prostate cancer $(n=4)$. The main sample consisted of 41 patients -22 females and 19 males - who completed 121 forms. The exclusion criteria involved: other diagnosed carcinomas or non-carcinoma diseases, more than one type of tumour and age below 18.

Quality of life was estimated using the QLQ-C15-PAL questionnaire recommended by the European Organization for Research and Treatment of Cancer (EORTC). The patients were asked to complete the questionnaires every week; all patients agreed to participate in the QOL assessments, giving their written informed consent.

The estimation of QOL was performed following 15 questions of QLQ-C15PAL comprising:

1. Functional scales.

1.1. Physical functioning (questions 1-3).

1.2. Emotional functioning (questions 13, 14). 2. Symptom scales.

2.1. Pain (questions 5,12 ).

2.2. Fatigue (questions 7,11 ).

2.3. Nausea and vomiting (question 9).

2.4. Additional symptoms (questions 4, 6, 8, 10).

3. Global quality of life (question 15).

For the global quality of life the 7-grade observer scale ranging from 1 (very poor) to 7 (excellent) was used. Functional scales (i.e. physical and emotional functioning) and symptom scales (fatigue, nausea and vomiting, pain, dyspnoea, insomnia, appetite loss, constipation) were 4-grade, ranging from 1 (not at all) to 4 (very much). In estimation of physical and emotional functioning and global quality of life, a high score represented a high level of functioning; a high score on the symptom scales represented a high level of symptomatology/problems.

The obtained results were analysed using the EORTC QLQ-C15-PAL Scoring Manual. The results referring to the several symptoms, physical and emotional functioning, and global quality of life were calculated according to:

$$
x=\left[\frac{(\text { score }-1)}{R-1}\right] \cdot 100
$$

score - the patient's answer in QLQ-C15-PAL questionnaire (values from 1 to 4 or 7$)$;

$R$ - range (the difference between the maximum and the minimum possible value);

$x$ - the recalculated score (values from 0 to 100).

The influence of the performed activities including palliative care on the quality of life was assessed according to scoring estimation following the questions of the QLQ-C15 PAL questionnaire completed during the first and last day of hospitalization.

\section{Statistical analysis}

The statistical analysis was performed using the software Statistica version 5.0, StatSoft. The statistical evaluation was performed using analysis of variance (ANOVA) and post-hoc comparisons were performed using the Duncan test. For dependent samples, $t$-test was used. Normal distribu- 
tion of a parameter was checked by means of KolmogorovSmirnov test with Lilliefors correction. The homogeneity of variance was tested by Levene's test. If data were not normally distributed or the values of variance were different, ANOVA with Kruskal-Wallis and Mann-Whitney's $U$ test were used.

All parameters were considered statistically significantly different if $p<0.05$.

\section{Results}

The performed study involved 41 patients who completed 121 QLQ-C15-PAL questionnaires. The mean age of patients was 68 years (46-85 years). During the study 20 patients died in the Palliative Care Unit; the most cases were related to lung cancer, the least to prostate cancer. The majority of patients were poorly capable of doing their daily routine activities (Table 1 ). The average period of hospitalization was 26 days (4-71 days).

The global quality of life in subjective patients' estimation was significantly $(p<0.05)$ higher in prostate and breast cancer as compared to patients with colon and lung cancer. Similarly, better results were recorded for emotional functioning. Patients with prostate and breast cancer obtained better results $(p<0.05)$ as compared to the others. All patients regardless of the type of tumour were characterized by poor physical functioning and daily activity, although with a lesser degree of discomfort in prostate cancer (Fig. 1).

For further assessment of QOL, the analysis comparing individual symptoms was performed. Generally, all groups of patients most frequently suffered from pain, loss of appetite and fatigue. Nausea and vomiting were under control.

Patients with prostate cancer obtained the best scores, considering the severity of several symptoms and discomfort. Loss of appetite, fatigue and pain in daily activities were characterized by lesser severity $(p<0.05)$ as compared to other patients. Oppositely, subjects with colon and breast cancer reported considerable discomfort including pain interfering with daily activities, loss of appetite and fatigue.
In most cases, the observed symptoms were significantly $(p<0.05)$ higher than in other patients (Fig. 2).

The performed activities contributing to palliative care insignificantly improved $(p>0.05)$ the emotional functioning of patients with colon, lung and breast cancer. The overall quality of life improved in patients with colon and breast cancer, giving similar scores to subjects with prostate cancer. The physical functioning remained poor or even became worse during the study period, however (Table 2).

Considering patients' answers to individual questions on the QLQ-C15-PAL form, a significant $(p<0.05)$ reduction of

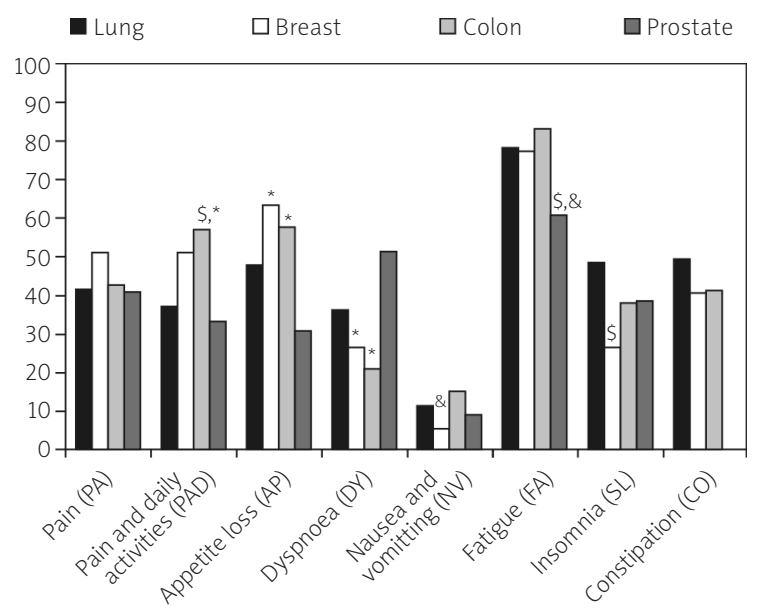

Fig. 1. The assessment of quality of life including individual symptoms in patients with lung, breast, colon and prostate cancer ${ }^{1}$ $\$$ as compared to patients with lung cancer $(p<0.05)$,

$\&$ as compared to patients with colon cancer $(p<0.05)$,

* as compared to patients with prostate cancer $(p<0.05)$,

1 high score represents a high level of symptomatology/problems Ryc. 1. Ocena jakości życia w odniesieniu do poszczególnych objawów u pacjentów z rakiem płuc, piersi, jelita grubego oraz prostaty ${ }^{1}$ $\$ w$ porównaniu z pacjentami z rakiem płuc $(p<0,05)$,

\& w porównaniu z pacjentami $z$ rakiem jelita grubego $(p<0,05)$,

* $w$ porównaniu z pacjentami z rakiem prostaty $(p<0,05)$,

${ }^{1}$ wyższa ocena punktowa oznacza wyższy stopień upośledzenia (dyskomfortu)

Table 1. Demographics and clinical characteristics of the study population Tabela 1. Ogólna charakterystyka pacjentów objętych badaniem

\begin{tabular}{|c|c|c|c|c|}
\hline Item & Variable & Number of patients (\%) & Number of questionnaires (\%) & Deaths (\%) \\
\hline Age groups & $\begin{array}{c}45-55 \\
56-65 \\
\geq 66\end{array}$ & $\begin{array}{l}17.07 \\
24.39 \\
58.54\end{array}$ & $\begin{array}{l}14.88 \\
28.10 \\
57.02\end{array}$ & $\begin{array}{r}42.86 \\
40.00 \\
54.17\end{array}$ \\
\hline Sex & $\begin{array}{l}\text { Female } \\
\text { Male }\end{array}$ & $\begin{array}{l}53.66 \\
46.34\end{array}$ & $\begin{array}{l}56.20 \\
43.80\end{array}$ & $\begin{array}{l}54.55 \\
42.10\end{array}$ \\
\hline Primary site & $\begin{array}{c}\text { Prostate } \\
\text { Colon } \\
\text { Lung } \\
\text { Breast }\end{array}$ & $\begin{array}{c}9.76 \\
39.02 \\
34.15 \\
17.07\end{array}$ & $\begin{array}{l}10.74 \\
42.15 \\
31.41 \\
15.70\end{array}$ & $\begin{array}{l}25.00 \\
37.50 \\
64.29 \\
57.14\end{array}$ \\
\hline Performance scale score* & $\begin{array}{c}\text { I } \\
\text { II } \\
\text { III } \\
\text { IV }\end{array}$ & $\begin{array}{c}- \\
4.88 \\
53.66 \\
41.46\end{array}$ & $\begin{array}{c}- \\
5.78 \\
52.07 \\
42.15\end{array}$ & $\begin{array}{c}- \\
0.00 \\
40.91 \\
64.71\end{array}$ \\
\hline
\end{tabular}

*According to physical functioning: I - able to walk and do light work, II - able to do routine, daily activities, III - limited ability to do routine, daily activities, $\mathrm{IV}$ - in bed most or all day 
somatic symptoms and discomfort involving nausea and vomiting, fatigue, insomnia or constipation was recorded. Some, but insignificant, decrease of pain complaints was observed, as well. The above results especially concerned patients with colon cancer. In other groups some reduction in severity of several symptoms such as pain, dyspnoea and insomnia (breast cancer) or constipation (prostate cancer) was denoted (Table 2). However, the above improvements were statistically insignificant. In patients with lung cancer no somatic symptoms were ameliorated (Table 2). No significant linkage between the performed activities contributing to QOL improvement and type of diagnosed tumour was detected.

\section{Discussion}

There is increasing awareness of the suffering of patients with terminal illnesses including pain and other physical and psychological symptoms. The objective of palliative care services is to improve the symptom control and quality of life of patients with terminal illnesses including cancer. With the increasing development of such services it is important to assess the effectiveness of the performed activities. Several studies and reviews have been published on palliative care to estimate the effectiveness of the palliative care services [7-12], and the quality of life was measured using several instruments. They involved for example the Multidimensional Quality of Life Scale-Cancer Version, the Medical Outcomes Study Short Form (SF-36, SF-20), the Functional Living Index-Cancer, and EORTC QLQ-C30. The latter one is an international, cancer-related core questionnaire developed by the European Organization for Research and Treatment of Cancer (EORTC) and is widely used in clinical trials for assessing physical and psychosocial symptoms and functioning of cancer patients. The short-

Table 2. The change of quality of life according to scoring estimation following the questions of QLQ-C15 PAL questionnaire completed during the first and last day of hospitalization (mean \pm SD)

Tabela 2. Zmiany jakości życia pacjentów na podstawie oceny punktowej według pytań zawartych w formularzu QLQ-C15 PAL wypetnionym $w$ pierwszym i ostatnim dniu hospitalizacji (średnia \pm SD)

\begin{tabular}{|c|c|c|c|c|c|c|c|c|c|}
\hline \multirow[t]{2}{*}{ Item } & \multirow[t]{2}{*}{ Question } & \multicolumn{2}{|c|}{ Lung cancer } & \multicolumn{2}{|c|}{ Breast cancer } & \multicolumn{2}{|c|}{ Colon cancer } & \multicolumn{2}{|c|}{ Prostate cancer } \\
\hline & & $1^{\text {st }}$ & last & $1^{\text {st }}$ & last & $1^{\text {st }}$ & last & $1^{\text {st }}$ & last \\
\hline \multirow[t]{3}{*}{$\begin{array}{l}\text { Physical } \\
\text { functioning }\end{array}$} & $\begin{array}{l}\text { Do you have any trouble taking a short } \\
\text { walk outside of the house? }\end{array}$ & & & & & & & & \\
\hline & $\begin{array}{l}\text { Do you need to stay in bed or chair } \\
\text { during the day? }\end{array}$ & $\begin{array}{c}18.16 \\
( \pm 16.08)\end{array}$ & $\begin{array}{c}18.19 \\
( \pm 19.11)\end{array}$ & $\begin{array}{l}22.23 \\
( \pm 22.18)\end{array}$ & $\begin{array}{l}14.66 \\
( \pm 9.90)\end{array}$ & $\begin{array}{c}24.46 \\
( \pm 21.71)\end{array}$ & $\begin{array}{c}25.0 \\
( \pm 21.28)\end{array}$ & $\begin{array}{c}28.3 \\
( \pm 6.36)\end{array}$ & $\begin{array}{c}28.32 \\
( \pm 6.36)\end{array}$ \\
\hline & $\begin{array}{l}\text { Do you need help with heating, dressing, } \\
\text { washing yourself or using the toilet? }\end{array}$ & & & & & & & & \\
\hline \multirow[t]{8}{*}{ Symptoms ${ }^{2}$} & Have you been short of breath? & $\begin{array}{c}45.45 \\
( \pm 37.33)\end{array}$ & $\begin{array}{c}42.42 \\
( \pm 39.69)\end{array}$ & $\begin{array}{c}38.89 \\
( \pm 39.00)\end{array}$ & $\begin{array}{c}20.00 \\
( \pm 18.26)\end{array}$ & $\begin{array}{c}27.78 \\
( \pm 19.24)\end{array}$ & $\begin{array}{c}22.22 \\
( \pm 32.82)\end{array}$ & $\begin{array}{c}58.33 \\
( \pm 31.91)\end{array}$ & $\begin{array}{c}58.33 \\
( \pm 41.94)\end{array}$ \\
\hline & Have you had pain? & $\begin{array}{c}51.51 \\
( \pm 34.52)\end{array}$ & $\begin{array}{c}48.48 \\
( \pm 40.45)\end{array}$ & $\begin{array}{c}61.11 \\
( \pm 25.09)\end{array}$ & $\begin{array}{c}33.33 \\
( \pm 40.82)\end{array}$ & $\begin{array}{c}58.33 \\
( \pm 28.87)\end{array}$ & $\begin{array}{c}41.67 \\
( \pm 35.18)\end{array}$ & $\begin{array}{c}41.67 \\
( \pm 16.67)\end{array}$ & $\begin{array}{c}50.00 \\
( \pm 19.24)\end{array}$ \\
\hline & Have you had trouble sleeping? & $\begin{array}{c}54.54 \\
( \pm 37.33)\end{array}$ & $\begin{array}{l}45.45^{\wedge} \\
( \pm 40.20)\end{array}$ & $\begin{array}{c}38.89 \\
( \pm 25.09)\end{array}$ & $\begin{array}{c}13.33 \\
( \pm 18.26)\end{array}$ & $\begin{array}{c}50.00 \\
( \pm 33.33)\end{array}$ & $\begin{array}{c}33.33 \\
( \pm 31.78)\end{array}$ & $\begin{array}{c}41.67 \\
( \pm 31.91)\end{array}$ & $\begin{array}{c}41.67 \\
( \pm 31.91)\end{array}$ \\
\hline & $\begin{array}{l}\text { Have you felt weak? } \\
\text { Have you been tired? }\end{array}$ & $\begin{array}{c}76.77 \\
( \pm 26.04)\end{array}$ & $\begin{array}{l}68.69^{*} \\
( \pm 34.00)\end{array}$ & $\begin{array}{c}76.77 \\
( \pm 34.44)\end{array}$ & $\begin{array}{c}77.77 \\
( \pm 28.34)\end{array}$ & $\begin{array}{c}92.60 \\
( \pm 12.82)\end{array}$ & $\begin{array}{c}81.50 \\
( \pm 19.73)\end{array}$ & $\begin{array}{c}63.87 \\
( \pm 26.28)\end{array}$ & $\begin{array}{c}69.47 \\
( \pm 13.97)\end{array}$ \\
\hline & Have you lacked appetite? & $\begin{array}{c}54.54 \\
( \pm 34.23)\end{array}$ & $\begin{array}{c}42.42 \\
( \pm 36.79)\end{array}$ & $\begin{array}{c}55.55 \\
( \pm 27.22)\end{array}$ & $\begin{array}{l}66.66 \\
( \pm 33.33)\end{array}$ & $\begin{array}{c}61.11 \\
( \pm 31.25)\end{array}$ & $\begin{array}{c}58.33 \\
( \pm 25.13)\end{array}$ & $\begin{array}{c}25.00 \\
( \pm 31.91)\end{array}$ & $\begin{array}{c}33.33 \\
( \pm 47.14)\end{array}$ \\
\hline & Have you felt nauseated? & $\begin{array}{c}9.10 \\
( \pm 15.57)\end{array}$ & $\begin{array}{c}13.64^{\star} \\
( \pm 29.64)\end{array}$ & $\begin{array}{c}8.33 \\
( \pm 20.41)\end{array}$ & $\begin{array}{c}3.34 \\
( \pm 7.47)\end{array}$ & $\begin{array}{c}31.96 \\
( \pm 35.85)\end{array}$ & $\begin{array}{c}6.96 \\
( \pm 8.60)\end{array}$ & $\begin{array}{c}0.00 \\
(-)\end{array}$ & $\begin{array}{c}25.00 \\
( \pm 28.87)\end{array}$ \\
\hline & Have you been constipated? & $\begin{array}{c}48.48 \\
( \pm 34.52)\end{array}$ & $\begin{array}{l}45.45^{*} \\
( \pm 37.33)\end{array}$ & $\begin{array}{c}27.78 \\
( \pm 25.09)\end{array}$ & $\begin{array}{c}46.67 \\
( \pm 44.72)\end{array}$ & $\begin{array}{c}50.00 \\
( \pm 33.33)\end{array}$ & $\begin{array}{c}33.33 \\
( \pm 28.43)\end{array}$ & $\begin{array}{c}50.00 \\
( \pm 43.03)\end{array}$ & $\begin{array}{c}25.00 \\
( \pm 31.91)\end{array}$ \\
\hline & $\begin{array}{l}\text { Has pain interfered with your } \\
\text { daily activities? }\end{array}$ & $\begin{array}{c}45.45 \\
( \pm 26.97)\end{array}$ & $\begin{array}{c}45.45 \\
( \pm 37.33)\end{array}$ & $\begin{array}{c}55.56 \\
( \pm 34.43)\end{array}$ & $\begin{array}{c}33.33 \\
( \pm 40.82)\end{array}$ & $\begin{array}{c}63.89 \\
( \pm 41.34)\end{array}$ & $\begin{array}{c}55.54 \\
( \pm 35.77)\end{array}$ & $\begin{array}{c}41.67 \\
( \pm 16.67)\end{array}$ & $\begin{array}{c}33.33 \\
( \pm 27.22)\end{array}$ \\
\hline $\begin{array}{l}\text { Emotional } \\
\text { functioning }\end{array}$ & $\begin{array}{l}\text { Have you felt tense? } \\
\text { Have you felt depressed? }\end{array}$ & $\begin{array}{c}31.08 \\
( \pm 19.04)\end{array}$ & $\begin{array}{l}42.44 \\
( \pm 25.95)\end{array}$ & $\begin{array}{c}61.12 \\
( \pm 24.52)\end{array}$ & $\begin{array}{c}56.68 \\
( \pm 25.26)\end{array}$ & $\begin{array}{c}29.87 \\
( \pm 28.53)\end{array}$ & $\begin{array}{c}40.30 \\
( \pm 20.05)\end{array}$ & $\begin{array}{c}62.52 \\
( \pm 27.62)\end{array}$ & $\begin{array}{c}68.77 \\
( \pm 23.92)\end{array}$ \\
\hline $\begin{array}{l}\text { Global } \\
\text { quality } \\
\text { of life }^{1}\end{array}$ & $\begin{array}{l}\text { How would you rate your } \\
\text { overall quality of life during } \\
\text { the past week? }\end{array}$ & $\begin{array}{c}25.76 \\
( \pm 15.57)\end{array}$ & $\begin{array}{c}27.27 \\
( \pm 13.48)\end{array}$ & $\begin{array}{c}33.33 \\
( \pm 25.82)\end{array}$ & $\begin{array}{c}53.33 \\
( \pm 27.39)\end{array}$ & $\begin{array}{c}20.83 \\
( \pm 20.26)\end{array}$ & $\begin{array}{c}31.94 \\
( \pm 19.40)\end{array}$ & $\begin{array}{c}50.00 \\
( \pm 13.60)\end{array}$ & $\begin{array}{c}50.00 \\
( \pm 13.60)\end{array}$ \\
\hline
\end{tabular}

*as compared to $1^{\text {st }}$ questionnaire $(p<0.05)$

$\wedge$ as compared to $1^{\text {st }}$ questionnaire $(p=0.052)$

${ }^{1}$ High score represents a high level of functioning

${ }^{2}$ High score represents a high level of symptomatology/problems 
ened version of QLQ-C30 is the newly developed QLQ-C15PAL form [5]. The QLQ-C15-PAL questionnaire consists of 15 items comprising: multi-item scales assessing physical and emotional functioning; symptom scales measuring fatigue, pain, nausea/vomiting, insomnia, dyspnoea, and constipation; and one scale estimating the global quality of life. The advantages of QLQ-C30 include: extensive validation, availability of reference data, many published studies for comparison, and standardized scoring procedures [5]. Possible disadvantages include its length (30 items) and some inappropriate contents when used in palliative patients. However, as compared to QLQ-C30, QLQC15-PAL, used in our study, was shortened to 15 items by eliminating some questions about physical, social and cognitive functioning, financial difficulties and global health status assessment.

The quality of life in subjective patients' assessment was scored from 0 to 7 , being significantly better in prostate or breast cancer (4.5 or higher) as compared to other subjects characterized by QOL below 3. The performed activities contributing to palliative care maintained or even improved the above parameter. In patients with colon or breast cancer the observed improvement was approximately $50 \%$, achieving scores similar to subjects with prostate cancer.

Emotional function was also an essential factor determining the overall QOL of patients hospitalized in the Palliative Care Unit. Anxiety and depression have been found in many previous studies as significant predictors of global QOL correlating with physical dysfunction and declining performance status [13], and appropriate treatment strategies for them are strongly recommended. Subjects with prostate and breast cancer were characterized by higher QOL and did not report such depression impairment as compared to those with colon or lung cancer. The performed activities slightly improved the emotional functioning of the majority of patients and no group was characterized by worsening of the mentioned parameter.

The overall quality of life was in correlation with primary carcinoma site, without any linkage to patients' age or sex. The performed study included only end-of-life patients with very poor physical functioning and receiving no anticancer treatment. However, the impact of several symptoms characterized by differential severity and specificity for any type of tumour should not be excluded. Overall poor QOL including both emotional functioning and somatic symptoms was observed especially in patients suffering from lung cancer. Moreover, the performed activities contributing to palliative care did not improve any symptoms or degree of discomfort. These findings were confirmed by others, indicating anxiety, depression, fatigue, and pain as common symptoms influencing QOL in lung cancer [13-16]. Similarly to our findings, patients with lung cancer experienced the most dramatic declines in physical functioning as well [17]. In contrast, patients with prostate cancer were characterized by better QOL scores and somatic symptoms.

Interestingly, patients with breast cancer were characterized by functional scales and subjective QOL comparable to subjects with prostate cancer but the severity of

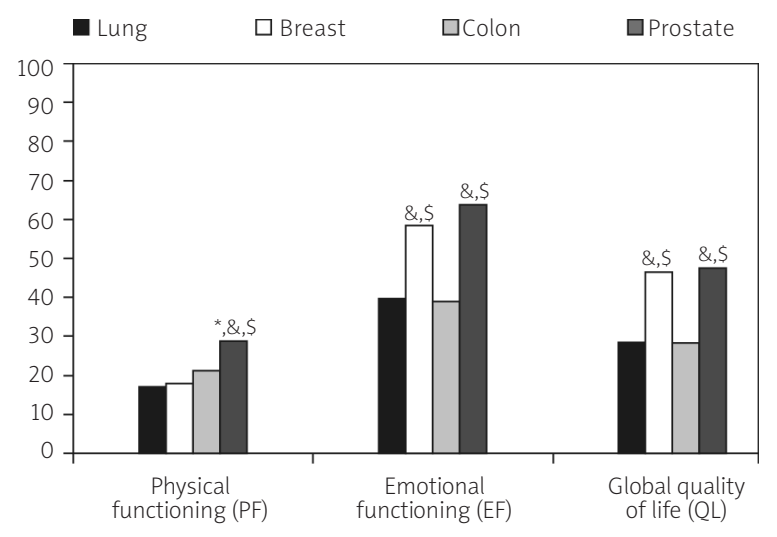

Fig. 2. The functional scales (PF, EF) and global quality of life in patients with lung, breast, colon and prostate cancer ${ }^{1}$ $\$$ as compared to patients with lung cancer $(p<0.05)$,

\& as compared to patients with colon cancer $(p<0.05)$,

* as compared to patients with breast cancer $(p<0.05)$,

1 high score represents a high level of functioning

Ryc. 2. Skala funkcjonalna (PF, EF) oraz subiektywna ocena jakości życia u pacjentów z rakiem płuc, piersi, jelita grubego oraz prostaty ${ }^{1}$ $\$ w$ porównaniu z pacjentami z rakiem płuc $(p<0,05)$,

\& w porównaniu z pacjentami z rakiem jelita grubego $(p<0,05)$,

* $w$ porównaniu z pacjentami z rakiem piersi $(p<0,05)$,

${ }^{1}$ wyższa ocena punktowa oznacza lepsza jakość życia

somatic symptoms (e.g. loss of appetite or fatigue) was considerable. However, other authors reported that patients with breast cancer experienced the smallest decline in physical functioning. In our study, terminally ill patients with incurable cancer were analysed, which may explain the differences. No significant linkage between the performed activities contributing to improvement of overall QOL or physical and emotional functioning and type of diagnosed tumour was observed, however.

Pain afflicts most cancer patients. It is suggested that the prevalence of pain in advanced cancer is about 70\%, with substantial variation according to the cancer type and disease stage [18]. In our study a high level of discomfort due to pain disturbances interfering with daily activities was also recorded in the majority of patients. Unfortunately, the pain management was shown to be insufficient, resulting in only slight improvement in some patients.

Management of pain related to advanced or metastatic cancer despite the availability of several pharmacological and non-pharmacological interventions and the existence of well-known guidelines and protocols is often difficult and inadequate. In a study performed in a Korean sample the authors, using QLQ-C30, reported that effective pain management in terminally ill patients might reduce the severity of other symptoms. In their observations the pain control not only resulted in some significant improvement of pain but also ameliorated other somatic symptoms (insomnia, constipation, diarrhoea) or emotional functioning, as well. Nevertheless, no improvement in other poor predictors of QOL such as physical functioning or fatigue was observed. Nevertheless, most reports emphasized that the pain management was still insufficient. A multicentre trial 
performed on a larger study group including 1801 patients assessing the adequacy of analgesic care in an Italian sample showed generally high non-compliance with the predefined set of clinical indicators ranging from 41 to $76 \%$. The authors suggested that the recourse to WHO thirdlevel drugs (strong opioids) still seemed delayed in a substantial percentage of patients and stated that it might be related to several factors affecting practice in participating centres [18].

Fatigue and weakness are other severe symptoms characterizing more than $90 \%$ of end-of-life patients. Similarly, those parameters were assessed as very poor in our study, negatively determining the overall QOL. Only patients with prostate cancer did not experience such strong fatigue and weakness symptoms, but the performed activities did not reduce the above parameters successfully. Other symptoms intensifying patients' discomfort were: insomnia, suggested to be the consequence of depression observed in the majority of patients, loss of appetite and other digestive disturbances (constipation). The conducted study did not demonstrate the complete elimination of the above symptoms, either. Moreover, considering the type of the diagnosed tumour, no statistically significant differences in the reduction of individual symptoms were found, either.

In one study on Hellenic Cooperative Oncology Group of patients using the EORTC QLQ-C30 questionnaire in terminally ill cancer patients, surprisingly a significant improvement of patients' functioning and all somatic symptoms was observed [19]. Nevertheless, the majority of existing studies have not provided conclusive evidence of satisfactory and sufficient palliative care management. Zimmermann et al. (2008) in a systematic review including 396 reports of clinical trials concluded that its benefits were still sparse and limited. The above meta-analysis analysed the results of several trials estimating the effectiveness of palliative care using different QOL instruments. The authors reported that only 4 of 13 studies assessing quality of life demonstrated a significant benefit of the specialized palliative care. However, only 1 of 14 analysed trials considering several somatic symptoms demonstrated significant effectiveness of performed activities and the improved symptoms were only dyspnoea, anxiety, and spiritual wellbeing [11]. Similarly, another meta-analysis demonstrated a small benefit in patients' pain and other symptoms and a non-significant trend towards benefits for satisfaction and therapeutic interventions [7]. The author stated that hospital-based palliative care teams offered some benefits. However, he suggested caution in such conclusions, indicating the need to use standardized outcome measures in similar research and in practice [9].

Another study (ENABLE II) found no success of the palliative care interventions mainly relating to QOL and emotional functioning. The authors analysed the effectiveness of such activities for 322 patients with advanced cancer, using Functional Assessment of Chronic Illness Therapy for Palliative Care, the Edmonton Symptom Assessment Scale, and the Centre for Epidemiological Studies Depression Scale for the assessment of QOL and degree of several symptoms.
The authors concluded that compared with participants receiving usual oncology care, those receiving a nurse-led, palliative care-focused intervention addressing physical, psychosocial, and care coordination provided concurrently with oncology care had higher scores for quality of life and mood. Nevertheless, patients did not show improvements in symptom intensity scores or reduced days in the hospital or ICU or emergency department visits [12].

Undoubtedly, considering the effectiveness of palliative care in such studies, we should not exclude some important factors including the region specificity with organization of Health Service or financial support. The above factors might impact significantly on the observed results.

A similar evaluation of quality of life, pain quality and intensity and care effectiveness in 50 Polish palliative care patients treated at the in-patient Palliative Care Department in Czestochowa was performed. The above parameters were assessed using other QOL instruments involving: Modified Sheet Pain Assessment, the Support Team Assessment Schedule (STAS), and the Rotterdam Symptom Checklist (RSCL). The results indicated poor patient performance status, lack of effective treatment and significant impairment of the psychological state. 52\% of patients achieved very high scores (poor effectiveness of treatment and care), $32 \%$ high scores (unsatisfactory treatment and care), and $15 \%$ average results (average treatment and care). Moreover, a decrease in physical activity and global quality of life of terminal patients was observed [20].

Palliative care at the end of life involves meeting the physical, psychological, social and practical needs of patients and caregivers [21]. Good clinical care can prevent or alleviate suffering for many subjects at the end of life by assessing symptoms and providing psychological and social support to the patients and their families. Symptom control, continuity in care and reducing caregiver burdens are critical elements of end-of-life care and appropriate treatment strategies for pain, dyspnoea or depression should still be a high priority, deserving specific attention to improve patients' outcomes. The unquestionable limitation of the performed study relates to the small size of the analysed groups, resulting from difficulties in recruiting patients admitted to hospital contemporaneously. The above factor might negatively impact on the power of statistical tests used in the performed analysis. Moreover, it precluded the performance of statistical analysis of the effectiveness of multidimensional activities in palliative care considering the improvement or worsening of QOL during treatment in the Palliative Medicine Unit. Even though the authors of this pivotal study have tried to investigate the physical and emotional functioning of patients with the most common carcinomas hospitalized in the Palliative Care Unit and to assess the effectiveness of palliative care, further studies are warranted to investigate the importance and effectiveness of specialized palliative care for patients' QOL. From the clinical point of view, with the increasing role of civilization diseases, including cancer, the continuous development of palliative medicine is undoubtedly needed. 
In conclusions:

1. The overall quality of life including somatic symptoms, emotional functioning and subjective QOL assessment of terminally ill palliative patients was determined by the type of tumour, giving the best scores in prostate cancer and the poorest ones in lung carcinoma.

2. The palliative care performed during the hospitalization period did not worsen the emotional functioning and overall QOL in patients' subjective assessment, giving no improvement of the above mentioned parameters in some subjects.

3. The different activities contributing to palliative care resulted in no impairment of several somatic symptoms (e.g. constipation, insomnia) determining the discomfort severity.

4. The important factors negatively determining the overall QOL were fatigue and pain, eliminated partially only in some patients.

5. The effectiveness of palliative care relating to overall QOL or improvement of individual symptoms did not differ significantly among patients with various types of tumour.

Praca finansowana przez UM w Łodzi: Nr 502-13-618, 5033011-2.

\section{References}

1. Raporty na podstawie danych Centrum Onkologii; available at: http://85.128.14.124/krn/ (28.08.09).

2. Cancer pain relief and palliative care. Report of WHO Expert Com mittee. Geneva, World Health Organization, 1990 (WHO Technical Report Series, nr 804).

3. Pierzchała W, Farnik-Brodzińska M. Jakość życia i jej ocena u chorych na astmę. Alergia Astma Immunologia 1997; 2: 203-6.

4. Camps C, del Pozo N, Blasco A, Blasco P, Sirera R. Importance of quality of life in patients with non-small-cell lung cancer. Clin Lung Cancer 2009; 10: 83-90.

5. Groenvold M, Petersen MA, Aaronson NK, Arraras JI, Blazeby JM, Bottomley A i wsp. EORTC Quality of Life Group: The development of the EORTC OLO-C15-PAL: a shortened questionnaire for cancer patients in palliative care. Eur J Cancer 2006; 42: 55-64.

6. EORTC QLQ-C15-PAL; available at: http://groups.eortc.be/qol/ questionnaires downloads.htm.

7. Higginson IJ, Finlay IG, Goodwin DM, Hood K, Edwards AG, Cook A Douglas HR, Normand CEJ. Is there evidence that palliative care teams alter end-of-life experiences of patients and their caregivers? J Pain Symptom Manage 2003; 25: 150-68.

8. Smeenk FW, van Haastregt JC, de Witte LP, Crebolder HF. Effectiveness of home care programmes for patients with incurable cancer on their quality of life and time spent in hospital: systematic review. BMJ 1998; 316: 1939-44

9. Higginson IJ, Finlay I, Goodwin DM, Cook AM, Hood K, Edwards AG, Douglas HR, Norman CEJ. Do hospital-based palliative teams improve care for patients or families at the end of life? Pain Symptom Manage 2002; 23: 96-106.

10. Salisbury C, Bosanquet N, Wilkinson EK, Franks PJ, Kite S, Lorent zon M, Naysmith A. The impact of different models of specialist palliative care on patients' quality of life: a systematic literature review. Palliat Med 1999; 13: 3-17.

11. Zimmermann C, Riechelmann R, Krzyzanowska M, Rodin G, Tannock I. Effectiveness of specialized palliative care: a systematic review. JAMA 2008; 299: 1698-709.

12. Bakitas M, Lyons KD, Hegel MT, Balan S, Brokaw FC, Seville J, Hull JG, Li Z, Tosteson TD, Byock IR, Ahles TA. Effects of a palliative care intervention on clinical outcomes in patients with advanced can- cer: the Project ENABLE II randomized controlled trial. JAMA 2009; 302: 741-9.

13. Henoch I, Bergman B, Gustafsson M, Gaston-Johansson F, Danielson E. The impact of symptoms, coping capacity, and social support on quality of life experience over time in patients with lung cancer. J Pain Symptom Manage 2007; 34: 370-9.

14. Carlsen K, Jensen AB, Jacobsen E, Krasnik M, Johansen C. Psychosocial aspects of lung cancer. Lung Cancer 2005; 47: 293-300.

15. Smith EL, Hann DM, Ahles TA et al. Dyspnea, anxiety, body consciousness, and quality of life in patients with lung cancer. J Pain Symptom Manage 2001; 21: 323-9.

16. Hollen PJ, Gralla RJ, Kris MG, Potanovich LM. Ouality of life assessment in individuals with lung cancer: testing the Lung Cancer Symptom Scale (LCSS). Eur J Cancer 1993; 29A Suppl 1: S51-S58.

17. Kurtz ME, Kurtz JC, Stommel M, Given CW, Given B. Physical functioning and depression among older persons with cancer. Cancer Pract 2001; 9: 11-8.

18. Apolone G, Corli O, Caraceni A, Negri E, Deandrea S, Montanari M, Greco MT; Cancer Pain Outcome Research Study Group (CPOR SG) Investigators. Pattern and quality of care of cancer pain management. Results from the Cancer Pain Outcome Research Study Group. Br J Cancer 2009; 100: 1566-74.

19. Kyriaki M, Eleni T, Efi P, Ourania K, Vassilios S, Lambros V: The EORTC core quality of life questionnaire (OLO-C30, version 3.0) in terminally ill cancer patients under palliative care: validity and reliability in a Hellenic sample. Int J Cancer 2001; 94: 135-9.

20. Kempińska E, Leppert W, Krzyianowski D. Assessment of quality of life, pain and effectiveness of treatment in palliative care patients. Rocz Akad Med Bialymst 2005; 50 Suppl 1: 207-9.

21. Qaseem A, Snow V, Shekelle P et al. Evidence-based interventions to improve the palliative care of pain, dyspnea, and depression at the end of life: a clinical practice guideline from the American College of Physicians. Ann Intern Med 2008; 148: 141-6.

\section{Address for correspondence:}

\section{Magdalena Jasińska}

Zakład Biofarmacji UM w Łodzi

ul. Muszyńskiego 1

90-151 Łódź

e-mail: magdalena.jasinska@umed.lodz.pl 